\title{
Parotid Epidermoid Carcinoma: A Case Report
}

\author{
Kambire $\mathbf{J L}^{1 *}$, Ouedraogo $\mathbf{S}^{1}$, Zida $\mathbf{M}^{2}$ and Traore $\mathbf{S S}^{2}$ \\ ${ }^{1}$ Ouahigouya's Teaching Hospital Center, Ouahigouya, Burkina Faso \\ 2Yalgado Ouedraogo's Teaching Hospital Center, Ouahigouya, Burkina Faso \\ "Corresponding author: Jean Luc Kambire, Ouahigouya's Teaching Hospital Center, Ouahigouya, Burkina Faso, Tel: 22670338914; E- \\ mail: jeanluckambire@yahoo.fr
}

Received date: June 22, 2017; Accepted date: June 27, 2017; Published date: June 30, 2017

Copyright: (c) 2017 Kambire JL, et al. This is an openaccess article distributed under the terms of the Creative Commons Attribution License, which permits unrestricted use, distribution, and reproduction in any medium, provided the original author and source are credited

\begin{abstract}
Introduction: Malignant parotid tumors are rare. They are characterized by their histological diversity dominated by muco-epidermoid tumors and adenocarcinomas; squamous cell carcinomas are much rarer.

Result: We report a case of carcinoma not very differentiated from the parotid evolving for 6 years to reach $15 \mathrm{~cm}$ of major axis at the time of its diagnosis in a 35-year-old woman.

Conclusion: Epidermoid carcinomas, although rare, are not exceptional. Their management is based on total parotidectomy provided that the diagnosis is early. Population education is required for a first-line use of health services in front of any indolor swelling in the parotid region.
\end{abstract}

Keywords: Malignant parotid tumor; Epidermoid carcinoma

\section{Introduction}

Parotid tumors refer to benign or malignant lesions, primitive or secondary, developed at the expense of the constituent elements of the gland. They are characterized by their clinical polymorphism and their histological diversity dominated by benign tumors. They accounted for $75 \%$ in the Essadi serie [1]. Malignant forms are rare and account for $3 \%$ to $5 \%$ of head and neck tumors [2]. If the mucoepidermoid tumors dominate the european series, the adenocarcinomas appear to be in the foreground in the african series [3,4]. As for squamous cell carcinomas, they are rarer. Through this observation and review of the literature, we discuss the epidemiological, clinical and histological aspects of malignant tumors of the parotid gland.

\section{Clinical Observation}

It was a 35-years-old patient admitted to a general surgical consultation for an ulcerative-necrotic and surinfected tumor of the left parotid region, which has been evolving for 6 years. Loco regional examination showed an ulcerous-tumefaction with necrosis plaques in the left parotid region, $15 \mathrm{~cm}$ long, with irregular boundaries, firm consistency, fixed to the deep plane; It was painful and haemorrhagic on contact. There was a peritumoral inflammatory reaction, a paresis of the facial nerve and fistulate confluent homolateral adenopathies. There was no evidence of trismus (Figure 1).

The contralateral region was apparently normal. The general examination revealed an alteration of the general condition, clinical anaemia and a fever at $38^{\circ} \mathrm{C}$. Examination of the pulmonary apparatus revealed a bilateral pulmonary condensation syndrome. The rest of the physical examination was normal. Cervical magnetic resonance imaging and the cervico-thoracic scan were prescribed, but not performed, as well as a chest X-ray. Severe anemia with a hemoglobin level of $4 \mathrm{~g} / \mathrm{dl}$ and leukocytosis of $16,000 \mathrm{cells} / \mathrm{mm}^{3}$ predominantly neutrophilic were detected in the biological examination. The patient had been hospitalized and medical treatment had been initiated. It consisted of analgesic and antibiotic administered parenterally, blood transfusion and local care. A biopsy of the lesion allowed, after histological examination, to conclude a squamous cell carcinoma. The degree of locoregional invasion did not allow surgical treatment; Also, palliative chemotherapy and radiotherapy were proposed but not honored due to their geographical and financial inaccessibility and the patient succumbed within 3 months of diagnosis.

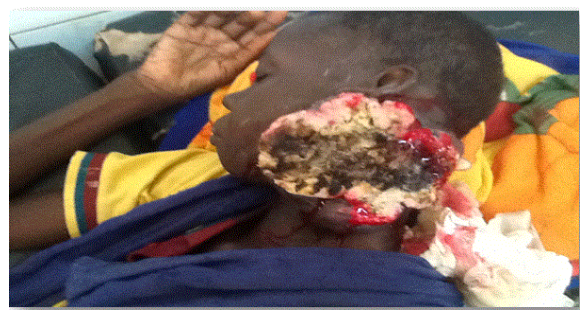

Figure 1: Clinical aspect of parotid epidermoid carcinoma.

\section{Discussion}

Malignant tumors of the parotid gland are rare; they represent $3 \%$ to $5 \%$ of head and neck tumors [2]. This rarity of malignant parotid tumors is confirmed by Sene and Nfoussi $[4,5]$ in Tunis with respective hospital frequencies of 1.2 and 2.6 cases/year. The case of our observation was female and was 35 years old. No sexual predominance is found in the literature. The age of our case corroborates the results of Sene [4] in Dakar and Ille [3] in Niger, who were respectively 37 and 38 years old, unlike Nfoussi [5] in Tunis who had an average age of 51. This difference could be explained by the high proportion of benign tumors in the Séné and Illé series. The reason for consultation is conventional: It is at the beginning of a painless parotid swelling, 
Citation: Kambire Jl, Ouedraogo S, Zida M, Traore SS (2017) Parotid Epidermoid Carcinoma: A Case Report. J Nucl Med Radiat Ther 8: 334.

Page 2 of 2

progressively extensive. In our observation, the swelling was ulceronercotic and surinfected due to delayed diagnosis. This long consultation period is classical in the african series $[3,4]$. It could be explained by the lack of knowledge of the disease and the primary use of care of traditional healers. The histological examination concluded to squamous cell carcinoma. It is a relatively rare epithelial malignant tumor. If the muco-epidermoid forms dominate the european series, parotid adenocarcinomas appear to be at the forefront in the african series. Séné [4] collected between 1981 and 2000, found no cases of squamous cell carcinoma; Nfoussi [5] over 5 years, noted 1 case and Illé [3] found 2 cases over 5 years. However, Anara [6] in Togo reported a higher frequency of squamous cell carcinoma of the parotid with $32.3 \%$ of cases. The treatments of malignant tumors of the parotid is based on surgery and consists of total parotidectomy with or without preservation of the facial nerve; According to the histological type and the tumor stage; chemotherapy and radiotherapy are associated. In laterally diagnosed forms, with no possibility of resection, as in the case of our observation, palliative chemotherapy and radiotherapy are appropriate. But in some parts of sub-Saharan Africa, these palliative therapies are geographically and financially inaccessible for most patients, condemning them to certain death, silent and probably earlier.

\section{Conclusion}

Epidermoid carcinomas, although rare, are not exceptional. Their management is based on total parotidectomy provided that the diagnosis is early. Palliative chemotherapy and radiotherapy exist for non-resectable tumors, but are not readily available in some areas in sub-Saharan Africa. Population education is required for a first-line use of health services in front of any painful swelling in the parotid region.

\section{References}

1. Essadi M, Jaji A, Janah A, Detsouli M, Kadiri F, et al. (1998) Parotid tumors: A report of 120 cases. Rev Laryngol Otol Rhinol 119: 177-182.

2. Bonfils P (2007) Tumeurs des glandes salivaires. EMC Oto Rhino Laryngol 20-628 : B-10.

3. Ille S, Timi N, Moussa RM (2016) Tumors of the parotid gland in Niger: Epidemiological, clinical and histological characteristics. Health Sci Dis 17: 63-66.

4. Séné I (2001) Study of parotid tumors in the ENT department of the CHU Aristide le Dantec. About 218 cases collected from January 1981 to December 2000.

5. Nfoussi H, Chelly I, Kharrof S (2012) Malignant tumors of the parotid. La Tunisie Médicale 90: 77-80.

6. Anara B, Peghesson E, Boko E (2014) Malignant tumors of the parotid. Rev Stomatol Chir Maxillo Fac 113: 13-16. 